\title{
PENINGKATAN KEAKTIFAN SISWA MENGIKUTI BELAJAR TAMBAHAN (BT) MELALUI LAYANAN KONSELING KELOMPOK DI SMP NEGERI 1 SOMOLOMOLO
}

\author{
Fatieli Lawolo ${ }^{1}$ * \\ 1) Guru SMP Negeri 1 Somolomolo Kabupaten Nias Sumatera Utara \\ E-mail: fatilawolo4@gmail.com
}

\begin{abstract}
Tujuan penelitian ini adalah (1) Mengetahui dan mendeskripsikan Peningkatan keaktifan siswa Kelas IXB SMP Negeri 1 Somolomolo dalam mengikuti BT. (2) Mengetahui dan mendeskripsikan dampak pelaksanaan layanan konseling kelompok di kelas IX-B SMP Negeri 1 Somolomolo Kabupaten Nias Tahun Pelajaran 2016/2017. Penelitian ini dilaksanakan di SMP Negeri 1 Somolomolo, kabupaten Nias dengan subjek penelitian siswa Kelas IX-B SMP Negeri 1 Somolomolo, Kabupaten Nias semester Genap Tahun Pelajaran 2016/2017 yang berjumlah 30 orang. Metode penelitian yang digunakan adalah penelitian tindakan kelas (PTK). Instrumen penelitian yang digunakan adalah (1) lembar observasi bagi siswa untuk mengetahui keaktifan mereka dalam pelaksanaan BT. (2) Pedoman Wawancara. (3) Dokumen. Berdasarkan analisis data, kegiatan layanan konseling kelompok di Kelas IX-B SMP Negeri 1 Somolomolo, Kabupaten Nias dapat meningkatkan keaktifan siswa dalam mengikuti BT dimana berdasarkan hasil refleksi pada akhir siklus keaktifan siswa mencapai $97 \%$.
\end{abstract}

Kata Kunci : Keaktifan Siswa, Konseling Kelompok 


\section{PENDAHULUAN}

Setiap tahun pemerintah menetapkan kriteria kelulusan melalui Prosedur Operasional Standar (POS) Ujian Nasional dan oleh karenanya setiap sekolah harus mempersiapkan siswa-siswanya mengikuti Ujian Nasional tersebut. Salah satu cara yang dilakukan di SMP Negeri 1 Somolomolo dalam mempersiapkan siswanya adalah dengan melaksanakan Belajar Tambahan (BT) bagi siswa-siswa kelas IX. Guru memberikan perbaikan-perbaikan dan pengayaan akan berbagai materi pelajaran khususnya pelajaran yang di UN-kan dengan mempedomani Kisi-kisi Ujian yang telah ditetapkan oleh Badan Standar Nasional Nasional (BSNP) sehingga siswa memiliki kesiapan dalam menghadapi Ujian Nasional.

Pelaksanaan Belajar Tambahan (BT) di sekolah bisa efektif dan bermanfaat bila guru merencanakan dan melaksanakannya dengan sungguh-sungguh dan siswa mengikutinya dengan baik. Dalam hal ini keseriusan dan keaktifan siswa merupakan kunci dari keberhasilan pelaksanaan program ini.

Keaktifan siswa dalam proses belajar mengajar merupakan salah satu kunci keberhasilan pencapaian tujuan pendidikan. Aktivitas merupakan asas yang terpenting dari asas-asas didaktik karena belajar sendiri merupakan suatu kegiatan dan tanpa adanya kegiatan tidak mungkin seseorang belajar. Aktivitas sendiri tidak hanya aktivitas fisik saja tetapi juga aktivitas psikis.

Kenyataan di lapangan menunjukan, pada pelaksanaan Belajar Tambahan (BT) pada sore hari banyak siswa yang tidak hadir, ada juga yang hanya sekedar hadir tetapi tidak serius. Banyak siswa yang malas mengerjakan tugas yang diberikan guru, ribut di kelas, melawan guru, nilai ujian rendah dan bahkan ada saja siswa yang tidak pernah hadir sama sekali.

Dari hasil observasi peneliti dan juga dari laporan guru mata pelajaran UN di antara tiga kelas yang ada, siswa Kelas IX-B yang sering sekali tidak datang pada pelaksanaan Belajar Tambahan (BT) ini. Pada Mata Pelajaran Bahasa Inggris siswa pernah 10 orang siswa tidak masuk, bahkan pada Mata Pelajaran Matematika pertama siswa yang tidak masuk hanya 6 orang tetapi setelah beberapa menit siswa keluar dan tidak kembali lagi ke dalam kelas sehingga pada akhirnya hanya 18 dari 30 orang siswa yang tinggal di dalam kelas.
NIAGAWAN Vol 8 No 1 Maret 2019

Bila hal ini dibiarkan maka sangat mempengaruhi keberhasilan siswa dalam belajar dan bahkan dapat berdampak pada nilai mereka di Ujian Nasional. Oleh karenanya masalah ini harus segera ditangani oleh pihak sekolah. Siswa yang mengalami permasalahan tersebut harus segera diberikan bantuan berupa bimbingan agar mereka dapat menyadari bahwa pelaksanaan belajar tambahan itu sangat membantu mereka dalam mendalami berbagai materi pelajaran serta untuk mempersiapkan mereka dalam menghadapi Ujian Nasional.

Dalam Peraturan Menteri Pendidikan Dan Kebudayaan Tentang Bimbingan Dan Konseling Pada Pendidikan Dasar Dan Pendidikan Menengah Nomor 111 tahun 2014 Pasal 1 Butir 1 dikatakan bahwa Bimbingan dan Konseling adalah upaya sistematis, objektif, logis, dan berkelanjutan serta terprogram yang dilakukan oleh konselor atau guru Bimbingan dan Konseling untuk memfasilitasi perkembangan peserta didik/Konseli untuk mencapai kemandirian dalam kehidupannya.

Menurut Prayitno yang dikutip oleh Suhertina (2008:2) bahwa bimbingan dan konseling membantu individu untuk menjadi insan yang berguna dalam kehidupannya yang memiliki berbagai wawasan, pandangan dan interpretasi, pilihan penyesuaian dan keterampilan yang tepat berkenaan dengan diri sendiri dan lingkungan. Namun, kenyataannya menunjukan bahwa di SMP Negeri 1 Somolomolo pelaksanaan layanan bimbingan yang diharapkan dapat membantu siswa mengenal bakat, minat, dan kemampuannya serta memilih dan menyesuaikan diri dengan kesempatan pendidikan belum berjalan efektif. Berdasarkan hal itu maka guru pembimbing sebagai salah satu tenaga pendidik di sekolah harus bisa memaksimalkan fungsinya sebagai konselor sekolah yang bertugas mengembangkan potensi dan memandirikan peserta didik.

Layanan konseling kelompok merupakan salah satu jenis layanan dalam Program Bimbingan dan Konseling yang dilaksanakan oleh guru pembimbing. Menurut Prayitno (2012:2), Layanan konseling kelompok adalah suatu cara memberikan bantuan (bimbingan) kepada individu (siswa) melalui kegiatan kelompok. Di dalam konseling kelompok topik yang dibahas masalah pribadi yang dialami oleh masing-masing anggota kelompok. Baik topik umum maupun masalah pribadi itu dibahas melalui suasana dinamika 
kelompok yang intens dan konstruktif, diikuti oleh semua anggota kelompok di bawah bimbingan pemimpin kelompok (Konselor).

Melalui layanan konseling kelompok ini siswa akan memperoleh kesempatan untuk membahas dan menyelesaikan permasalahan yang dialaminya melalui dinamika kelompok. Sukardi (2008:49) mengatakan bahwa dinamika kelompok merupakan suasana yang hidup, yang berdenyut, yang bergerak, yang berkembang, yang ditandai dengan adanya interaksi antar sesama anggota kelompok.

Layanan konseling kelompok dipandang tepat untuk memberikan kontribusi pada siswa kelas IX-B dalam memecahkan masalah yang dihadapinya terutama masalah yang berkaitan dengan keaktifan dalam mengikuti Belajar Tambahan (BT) karena masalah kurang aktif tersebut merupakan masalah pribadi yang telah menjadi masalah bersama. Dalam pelaksanaan layanan konseling kelompok, siswa sebagai anggota kelompok akan bersama-sama membahas topik-topik masalah mengenai meningkatkan diri dan menciptakan dinamika kelompok yang dapat dijadikan tempat untuk mengembangkan keaktifan belajar.

Anggota kelompok akan mempunyai hak yang sama untuk melatih diri dalam mengemukakan pendapatnya, membahas masalah yang dialaminya dengan tuntas, siswa dapat saling tukar informasi, memberi saran dan belajar memecahkan masalah yang dihadapi anggota bersama-sama, dapat berbagi pengalaman dan diskusi, sehingga dapat meningkatkan keaktifan mereka dalam belajar dan dalam mengikuti progran Belajar Tambahan.

\section{TINJAUAN PUSTAKA}

\section{Keaktifan Siswa}

Menurut Djamarah (2010:362), belajar aktif ditunjukkan dengan adanya ketertiban intelektual dan emosional yang tinggi dalam proses belajar. Siswa diberikan kesempatan untuk berdiskusi mengemukakan pendapat dan idenya, melakukan ekslorasi terhadap materi yang sedang dipelajari serta menafsirkan hasilnya secara bersama-sama di dalam kelompok. Kegiatan tersebut memungkinkan siswa berinteraksi aktif dengan lingkungan dan kelompoknya, sebagai media untuk mengembangkan kemampuannya.

Ahmadi \& Supriyono (2008:207) mengunagkapkan bahwa siswa aktif adalah siswa yang terlibat secara intelektual dan
NIAGAWAN Vol 8 No 1 Maret 2019

emosional dalam kegiatan belajar. Senada dengan pendapat tersebut Yusmiati (2010:10) mengatakan bahwa siswa aktif adalah siswa yang terlibat secara fisik, psikis, intelektual dan emosional secara terus menerus dalam proses pembelajaran.

Sudjana (2010:110) mengatakan bahwa seseorang yang melakukan aktivitas belajar ditandai dengan ciri-ciri seperti: (1) Siswa tidak hanya menerima informasi, tetapi lebih banyak mencari dan memberi informasi. Siswa banyak mengajukan pertanyaan baik kepada guru maupun kepada siswa yang lainnya; (2) Siswa lebih banyak mengajukan tanggapan, pendapat, terhadap informasi yang disampaikan oleh guru atau terhadap pendapat yang diajukan oleh siswa lain; (3) Siswa memberikan respon nyata terhadap stimulus belajar yang diberikan oleh guru seperti membaca, mengerjakan tugas, mendiskusikan pemecahan masalahnya dengan teman sekelas, bertanya kepada siswa lain bila mendapat kesulitan, mencari informasi dari beberapa sumber belajar, dan kegiatan nyata lainnySiswa berkesempatan melakukan penilaian sendiri; (4) hasil pekerjaannya, sekaligus memperbaiki dan menyempurnakan pekerjaan yang dianggapnya masih belum sempurna; (6) Siswa membuat sendiri kesimpulan pelajaran dengan bahasa dan cara masing-masing baik secara mandiri maupun secara berkelompok; dan (7) Siswa memanfaatkan sumber belajar atau lingkungan belajar yang ada di sekitarnya secara optimal dalam kegiatannya, merespon stimulus belajar yang diberikan oleh guru.

\section{Belajar Tambahan}

Belajar Tambahan (BT) ini merupakan sebuah program belajar yang dilaksanakan di luar program intrakurikuler sekolah. Program kegiatan belajar tambahan ini biasanya dibimbimbing oleh guru mata pelajaran di sekolah bersangkutan.

Tujuan diadakannya belajar tambahan adalah untuk meningkatkan pemahaman dan pendalaman terhadap materi suatu mata pelajaran. Tujuan ini berkaitan dengan persiapan seorang siswa untuk menghadapi ujian di sekolah, baik ujian tengah semester, ujian akhir semester maupun ujian akhir nasional.

Dengan mengikuti belajar tambahan, siswa akan mengalami ketuntasan belajar, mereka dapat menguasai materi suatu mata pelajaran dengan baik dan mampu mengatasi 
kesulitan belajar pada mata pelajaran tertentu di sekolah serta agar mereka memperoleh nilai yang maksinal.

Ada beberap manfaat Belajar Tambahan itu diberikan kepada siswa yakni: (1) Siswa lebih memahami materi pelajaran; (2) Siswa menjadi terampil dalam mengerjakan soal-soal ujian; (3) Siswa mampu beradaptasi dengan berbagai bentuk dan corak soal yang akan diuji dalam ujian; (4) Siswa berpeluang besar untuk memperoleh nilai bagus pada berbagai bentuk ujian sekolah; dan (5) Siswa berpeluang besar untuk berhasil lulus pada ujian nasional. (Maulidy, 2015)

\section{Layanan Konseling Kelompok}

Menurut Rusmana (2009:29), Konseling

Kelompok merupakan suatu upaya pemberian bantuan kepada individu (konseli) yang dilakukan dalam suasana kelompok, bersifat pencegahan dan penyembuhan serta bertujuan untuk memberikan kemudahan dalam berbagai aspek perkembangan dan pertumbuhannya. Senada dengan itu, Sukardi (2008:49) mengatakan bahwa layanan konseling kelompok adalah layanan bimbingan dan konseling yang memungkinkan peserta didik memperoleh kesempatan untuk pembahasan dan pengentasan permasalahan yang dialaminya melalui dinamika kelompok.

Selanjutnya menurut Prayitno (2004), layanan konseling kelompok pada dasarnya adalah layanan konseling perorangan yang dilaksanakan didalam suasana kelompok. Disana ada konselor dan ada klien, yaitu para anggota kelompok (yang jumlahnya minimal dua orang). Disana terjadi hubungan konseling dalam suasana yang diusahakan sama seperti dalam konseling perorangan yaitu hangat, permisif, terbuka dan penuh keakraban. Dimana juga ada pengungkapan dan pemahaman masalah klien, penelusuran sebab-sebab timbulnya masalah, upaya pemecahan masalah (jika perlu dengan menerapkan metode-metode khusus), kegiatan evaluasi dan tindak lanjut.

Dari pengertian tersebut di atas maka dapat disimpulkan bahwa layanan konseling kelompok merupakan layanan dalam bimbingan dan konseling yang membahas permasalahanpermasalahan pribadi yang dialami anggota dalam suatu kelompok dengan memanfaatkan dinamika kelompok.

Layanan konseling kelompok memiliki dua aspek tujuan, yakni umum dan khusus.
Tujuan umum dilaksanakan layanan konseling kelompok agar kemampuan berkomunikasi siswa dapat berkembang. Komunikasi di sini bukan hanya di tekankan pada komunikasi kelompok namun komunikasi hangat antarpribadi. Hal ini didasarkan pada pendapat Tohirin (2013:179), bahwa secara umum tujuan layanan konseling kelompok adalah berkembangnya kemampuan sosialisasi siswa, khususnya kemampuan berkomunikasinya.

$\begin{array}{ccc}\text { Menurut } & \text { Prayitno } & (2004: 170) \\ \text { pelaksanaan } & \text { Konseling } & \text { Kelompok }\end{array}$
diselenggarakan melalui empat tahap kegiatan, yaitu :

1. Tahap pembentukan, yaitu tahap untuk membentuk sejumlah individu menjadi satu kelompok yang siap mengembangkan dinamika kelompok untuk mencapai tujuan bersama

2. Tahap peralihan, yaitu tahapan untuk mengalihkan kegiatan awal kelompok ke kegiatan berikutnya yang lebih terarah pada pencapaian tujuan kelompok.

3. Tahap kegiatan, yaitu tahap "kegiatan inti" untuk membahas topik-topik tertentu atau mengentaskan masalah pribadi anggota kelompok.

4. Tahap pengakhiran, yaitu tahapan akhir kegiatan untuk melihat kembali apa yang sudah dilakukan dan dicapai oleh kelompok, serta merencanakan kegiatan selanjutnya.

\section{METODE PENELITIAN}

Jenis penelitian yang digunakan adalah penelitian tindakan kelas. Penelitian ini dilaksanakan di SMP Negeri 1 Somolomolo Kec. Somolomolo Kab. Nias. Subjek penelitian ini adalah siswa kelas Kelas IX-B SMP Negeri 1 Somolomolo sebanyak 30 orang yang terdiri dari laki-laki 16 orang dan perempuan 14 orang. Penelitian dilaksanakan pada Semester Genap tahun pembelajaran 2016/2017 yaitu pada bulan Februari sampai dengan April 2017. Prosedur pelaksanaan tindakan adalah sebagai berikut: 


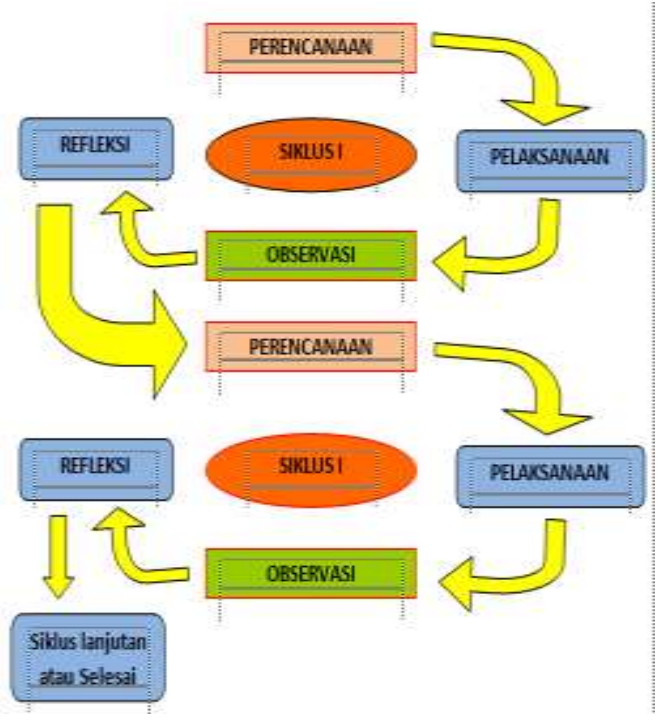

Gambar 1. Prosedur Penelitian Tindakan

Instrumen penelitian yang digunakan adalah observasi, wawancara, dan dokumentasi. Teknik analisis data yang digunakan adalah analisis data kualitatif.

\section{HASIL DAN PEMBAHASAN}

Pada kondisi awal peneliti menemukan masalah di kelas IX-B SMP Negeri 1 Somolomolo pada pelaksanaan program Belajar Tambahan (BT) banyak siswa tidak hadir. Berdasarkan hasil pengamatan yang dilakukan selama tiga kali pelaksanaan Belajar Tambahan secara berturut turut pada tanggal 1, 3 dan 6 Februari 2017 diperoleh data kehadiran siswa, yaitu dari 30 orang siswa kelas IX-B ada 12 orang siswa yang pernah tidak hadir pada pelaksanaan BT. Hal ini menunjukan bahwa siswa kelas IX-B yang aktif hanya $60 \%$ dan yang tidak aktif 40\%. Kemudian dari hasil wawancara kepada guru pembimbing mata pelajaran BT bahwa di antara siswa tersebut ada yang hadir pada les pertama tetapi pada les kedua atau sebaliknya. Dari hal tersebut maka peneliti merasa yakin bahwa kepada siswa kelas IX-B ini sangat perlu dilakukan tindakan dengan memberikan layanan konseling kelompok.

\section{Siklus I}

a. Perencanaan

Berdasarkan data pada pengamatan awal tersebut peneliti merencanakan melakukan tindakan dengan melaksanakan Layanan Konseling Kelompok kepada siswa yang tidak aktif pada pelaksanaan BT di kelas IX-B. Jumlah siswa yang diberikan layanan Konseling Kelompok ada 12 orang dan menggunakan waktu 2 x 40 menit.

b. Pelaksanaan
NIAGAWAN Vol 8 No 1 Maret 2019

Pelaksanaan Konseling Kelompok pada siklus I diawali dengan Tahap pembentukan. Dalam hal ini Guru pembimbing membentuk kelompok, menyampaikan salam dan memimpin doa bersama. Kemudian melakukan perkenalan dan menyampaikan tujuan pelaksnaan Konseling kelompok.

Pada Tahap peralihan, Guru menyampaikan peranan masing-masing kelompok dan membimbing siswa menjaga suasana interaktif yang kondusif. Selanjutnya pada Tahap kegiatan, ditetapkan masalah kelompok yang perlu dibahas untuk diselesaikan secara bersama dan kemudian Guru menjelaskan Manfaat Pelaksanaan Belajar Tambahan (BT).

Pada tahap akhir, masing-masing siswa menyampaikan kesimpulan dan keputusan yang diambilnya. Kemudian kegiatan ditutup dengan melakukan permainan sehingga siswa merasa senang

c. Pengamatan

Setelah selesai layanan Konseling kelompok pada Siklus I ini, Peneliti bekerjasama dengan guru pembimbing mata pelajaran BT melakukan pengamatan terhadap kehadiran siswa kelas IX-B tersebut selama 3 kali berturut-turut yakni pada tanggal 8 Februari 2017, 10 Februari 2017 dan 13 Februari 2017. Dari hasil pengamatan tersebut diperoleh data, dari 30 orang siswa kelas IX-B tinggal 5 orang siswa yang pernah absen pada pelaksanaan BT.

d. Refleksi

Bila pada pra siklus siswa yang tidak aktif 12 orang dan setelah siklus I siswa yang tidak aktif ada 5 orang. Dari hal itu maka siswa yang aktif bertambah dari 18 orang menjadi 25 orang (terjadi peningkatan sebesar 23\%). Berhubung peningkatan ini masih belum maksimal maka perlu dilanjutkan tindakan pada siklus ke II.

\section{Siklus II}

a. Perencanaan

Dari hasil pengamatan dan refleksi pada siklus I masih ada 5 orang siswa yang pernah absen dalam pelaksanaan Belajar Tambahan (BT). Oleh karenanya direncanakan kembali kepada 5 orang siswa tersebut akan diberikan layanan Konseling Kelompok oleh guru pembimbing. Waktu yang digunakan $2 \mathrm{x}$ 40 menit

b. Pelaksanaan

Langkah-langkah pemberian layanan pada sama pada siklus I. Guru bertindak 
sebagai pemimpin kelompok. Kegiatan yang dilakukan pada tahap pembentukan dimulai dari doa kemudian masingmasing anggota kelompok memperkenalkan diri.

Pada tahap peralihan anggota diajak untuk bernyanyi bersama dan kelompok kegiatan inti guru mengajak siswa mendiskusikan kerugian yang mereka alami bila tidak serius dalam belajar. Pada akhir kegiatan mereka menyampaikan komitmen masingmasing tanpa ada paksaan dari guru

c. Pengamatan

Setelah selesai layanan Konseling kelompok pada Siklus II ini, Peneliti bekerjasama dengan guru pembimbing mata pelajaran BT melakukan pengamatan terhadap kehadiran siswa kelas IX-B tersebut selama 3 kali berturut-turut yakni pada tanggal 17, 20 dan 22 Februari 2017. Dari hasil pengamatan tersebut diperoleh data, dari 30 orang siswa kelas IX-B tinggal 1 orang siswa yang pernah absen pada pelaksanaan BT

d. Refleksi

Bila pada siklus I siswa yang tidak aktif 5 orang dan setelah siklus II siswa yang pernah tidak hadir tinggal 1 orang. Hal ini menunjukan bahwa siswa yang akti bertambah dari 25 orang pada siklus I menjadi 29 orang. Ada peningkatan sebesar $13 \%$ dari siklus I atau $37 \%$ dari pra siklus.

Setelah peneliti memberikan tindakan pada peserta didik Kelas IX-B SMP Negeri 1 Somolomolo dengan pelaksanaan Konseling Kelompok maka diperoleh hasil sebagai berikut:

1. Dengan pelaksanaan konseling Kelompok, keaktifan peserta didik dalam mengikuti Belajar Tambahan (BT) menjadi meningkat.

2. Dari data kondisi awal sampai kondisi akhir menunjukkan adanya peningkatan keaktifan peserta didik dalam mengikuti pelaksanaan Belajar Tambahan (BT). Tingkat keaktifan siswa mencapai $97 \%$. Hal ini menunjukan peningkatan sebesar $37 \%$.

3. Berdasarkan kenyataan dan pengamatan yang dilakukan, pelaksanaan Konseling Kelompok dapat menuntaskan permasalahan peserta didik yang mereka alami khususnya dalam masalah ketidakaktifan dalam belajar.

Untuk lebih jelas tentang peningkatan keaktifan peserta didik dimaksud dapat dilihat dalam grafik berikut:

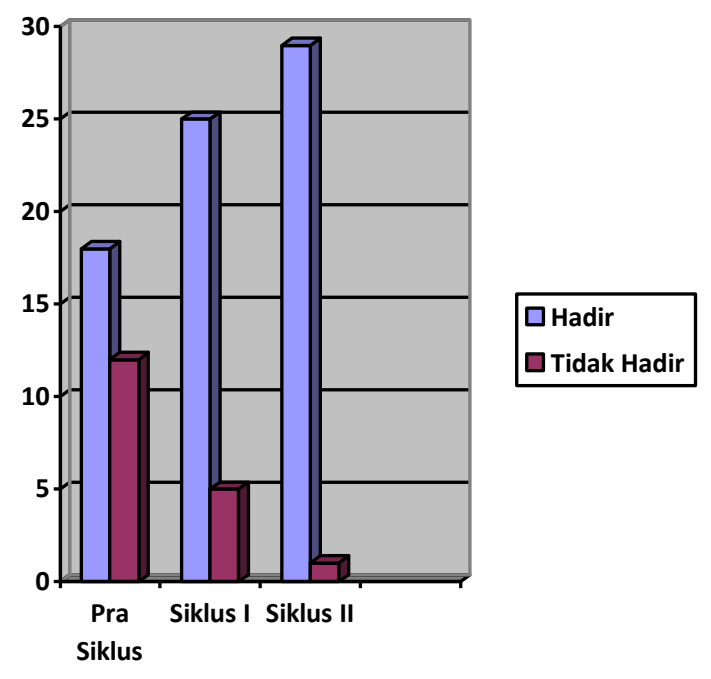

Gambar 2. Grafik Peningkatan Keaktifan Siswa

\section{KESIMPULAN DAN SARAN}

Dari hasil pengolahan data dapat disimpulkan bahwa dengan layanan Konseling Kelompok dapat meningkatkan keaktifan siswa dalam mengikuti pelaksanaan Belajar tambahan (BT). Tingkat keaktifan peserta didik mencapai 97\%. Terjadi peningkatan sebesar $37 \%$.

\section{Saran}

Adapun saran penelitian ini adalah: 1) Guru mata pelajaran hendaknya lebih meningkatkan kerja sama dengan Guru pembimbing dalam menangani permasalahan-permasalahan yang dialami peserta didik di sekolah, 2) Diharapkan agar guru pembimbing lebih aktif dan kreatif dalam menentukan jenis layanan yang dipilih dalam membantu peserta didik menyelesaikan masalahnya, 3) Sekolah hendaknya memberikan kesempatan kepada guru pembimbing dalam upaya pengentasan permasalahan peserta didik dengan menyediakan waktu dan tempat pelaksanaan layanan konseling.

\section{REFERENSI}

Ahmadi, Abu dan Supriyono, Widodo. 2008. Psikologi Belajar. Jakarta: Rineka Cipta.

Maulidy, Bintang. 2015. Inilah Manfaat Belajar Tambahan Bagi Siswa. https://www.utakatikotak.com/kongkow/d etail/4633/-Inilah-Manfaat-BelajarTambahan-bagi-Siswa

Peraturan Menteri Pendidikan Dan Kebudayaan Tentang Bimbingan Dan Konseling Pada Pendidikan Dasar Dan Pendidikan Menengah Nomor 111 tahun 2014 
Prayitno. 2004. Layanan Bimbingan Kelompok dan Konseling Kelompok. Padang: FIP UNP.

Rusmana, Namdang. 2009. Bimbingan dan Konseling Kelompok di Sekolah. Bandung: Rizqi.

Sudjana, Nana. 2010. Cara Belajar Siswa Aktif Dalam Proses Belajar Mengajar. Jakarta: Sinar Baru Algesindo.

Suhertina, 2008. Pengantar Bimbingan dan Konseling di Sekolah, Pekanbaru: Suska Press.

Sukardi, Dewa Ketut. 2008. Pengantar Pelaksanaan Program Bimbingan Dan Konseling Di Sekolah. Jakarta: Rineka Cipta.

Tohirin, 2013. Bimbingan dan Konseling di Sekolah dan Madrasah. Jakarta: Raja Grafindo Persada. 